\title{
Current Evidence and Possible Future Applications of Creatine Supplementation for Older Adults
}

\author{
Darren G. Candow ${ }^{1, *}$, Scott C. Forbes ${ }^{2} \oplus$, Ben Kirk ${ }^{3,4} \oplus$ and Gustavo Duque ${ }^{3,4}(\mathbb{C}$ \\ 1 Faculty of Kinesiology and Health Studies, University of Regina, Regina, SK S4SOA2, Canada \\ 2 Department of Physical Education Studies, Faculty of Education, Brandon University, \\ Brandon, MB R7A6A9, Canada; forbess@brandonu.ca \\ 3 Department of Medicine-Western Health, The University of Melbourne, Parkville, VIC 3021, Australia; \\ ben.kirk@unimelb.edu.au (B.K.); Gustavo.duque@unimelb.edu.au (G.D.) \\ 4 Australian Institute for Musculoskeletal Science (AIMSS), The University of Melbourne and Western Health \\ St. Albans, VIC 3201, Australia \\ * Correspondence: Darren.Candow@uregina.ca; Tel.: +1-306-585-4906
}

Citation: Candow, D.G.; Forbes, S.C. Kirk, B.; Duque, G. Current Evidence and Possible Future Applications of Creatine Supplementation for Older Adults. Nutrients 2021, 13, 745 . https://doi.org/10.3390/nu13030745

Academic Editor: David C. Nieman

Received: 6 January 2021

Accepted: 20 February 2021

Published: 26 February 2021

Publisher's Note: MDPI stays neutral with regard to jurisdictional claims in published maps and institutional affiliations.

Copyright: () 2021 by the authors. Licensee MDPI, Basel, Switzerland. This article is an open access article distributed under the terms and conditions of the Creative Commons Attribution (CC BY) license (https:// creativecommons.org/licenses/by/ $4.0 /)$.

\begin{abstract}
Sarcopenia, defined as age-related reduction in muscle mass, strength, and physical performance, is associated with other age-related health conditions such as osteoporosis, osteosarcopenia, sarcopenic obesity, physical frailty, and cachexia. From a healthy aging perspective, lifestyle interventions that may help overcome characteristics and associated comorbidities of sarcopenia are clinically important. One possible intervention is creatine supplementation (CR). Accumulating research over the past few decades shows that $C R$, primarily when combined with resistance training (RT), has favourable effects on aging muscle, bone and fat mass, muscle and bone strength, and tasks of physical performance in healthy older adults. However, research is very limited regarding the efficacy of CR in older adults with sarcopenia or osteoporosis and no research exists in older adults with osteosarcopenia, sarcopenic obesity, physical frailty, or cachexia. Therefore, the purpose of this narrative review is (1) to evaluate and summarize current research involving CR, with and without $\mathrm{RT}$, on properties of muscle and bone in older adults and (2) to provide a rationale and justification for future research involving CR in older adults with osteosarcopenia, sarcopenic obesity, physical frailty, or cachexia.
\end{abstract}

Keywords: sarcopenia; osteoporosis; osteosarcopenia; frailty; cachexia

\section{Introduction}

Sarcopenia refers to age-related reductions in muscle strength (dynapenia), muscle mass (quantity), relative strength (strength per unit of muscle mass), muscle quality (architecture and composition), and/or physical performance (i.e., tasks of functionality) [1]. Sarcopenia typically occurs in $8-13 \%$ of adults $\geq 60$ years of age [2] and is associated with other agerelated health conditions such as osteoporosis, osteosarcopenia, sarcopenic obesity, physical frailty, and cachexia. Annually, muscle mass decreases by $0.45 \%$ in men and by $0.37 \%$ in women, but these decrements climb to $0.9 \%$ for men and to $0.7 \%$ for women starting in their seventh decade [3]. The age-related decrease in muscle strength, which is a strong predictor of poor health outcomes (mobility disability, falls, fractures, and mortality) in older adults [1], occurs more rapidly (2-5 fold faster) than the reduction in lean (muscle) mass [4].

From a global health perspective, the World Health Organization established a code (ICD-10-CM; M62.84) for sarcopenia as a means for better diagnosis, assessment, and treatment of the condition. While several definitions and subcategories of sarcopenia exist, the European Working Group on Sarcopenia in Older People (EWGSOP) defines individuals with low muscle strength (as assessed by grip-strength or chair-stand test) as having probable sarcopenia; those with low muscle strength and low muscle quantity (as assessed by dual energy $\mathrm{X}$-ray absorptiometry, magnetic resonance imaging and 
spectroscopy, computed tomography, bioelectrical impedance, creatine dilution, and/or muscle biopsy) as having confirmed sarcopenia; and those with low muscle strength, low muscle quantity, and poor physical performance (as assessed by gait speed, short physical performance battery test, timed-up-and-go test, or $400 \mathrm{~m}$ walk test) as having severe sarcopenia [1]. Sarcopenia is classified as primary when its etiology is age dependent whereas secondary sarcopenia is influenced by age and/or other factors such as physical inactivity and undernutrition [1]. Contributing factors to the pathophysiology of sarcopenia include changes in neuromuscular function, skeletal muscle morphology and architecture, protein kinetics, hormonal regulation, growth factors and satellite cells, vascularization, inflammation, mitochondrial function, nutrition, and physical activity $[1,3,4]$. From a healthy aging perspective, interventions that may help overcome characteristics and associated comorbidities of sarcopenia (i.e., osteoporosis, osteosarcopenia, sarcopenic obesity, physical frailty, and cachexia) are clinically important.

Accumulating research over the past few decades shows that creatine supplementation (CR), primarily when combined with resistance training (RT), has some favourable effects on muscle accretion and bone mineral density, bone and muscle strength, and tasks of functionality in older adults (for reviews, see Candow et al. [5], Chilibeck et al. [6], Forbes et al. [7], Gualano et al. [8], and Kreider et al. [9]). However, research is very limited regarding the efficacy of CR in older adults with sarcopenia or osteoporosis and no research exists in older adults with osteosarcopenia, sarcopenic obesity, physical frailty, or cachexia. Therefore, the purpose of this narrative review is (1) to evaluate and summarize current research involving $C R$, with and without $\mathrm{RT}$, on properties of muscle and bone in older adults and (2) to provide a rationale and justification for future research involving CR in older adults with osteosarcopenia, sarcopenic obesity, physical frailty, or cachexia.

\section{Creatine}

Creatine is an organic acid endogenously synthesized from reactions involving the amino acids arginine, glycine, and methionine in the kidneys and liver [10]. Alternatively, creatine can be exogenously consumed from meat [9] and commercially manufactured products. The vast majority $(\approx 95 \%)$ of creatine resides in skeletal muscle, with approximately $66 \%$ being stored as phosphocreatine (PCr) [9]. It is estimated that $2 \%$ of endogenous creatine stores are degraded daily to creatinine, a metabolic by-product of creatine metabolism [10]. For most individuals, excluding vegans and vegetarians, $\approx 3 \mathrm{~g}$ of exogenous creatine per day may help maintain creatine stores [9]. Metabolically, creatine combines with inorganic phosphate (Pi) to form $\mathrm{PCr}$, which helps resynthesize and maintain adenosine triphosphate (ATP) levels [9].

\section{Potential of Creatine Supplementation for Sarcopenia}

The majority of aging research involving CR has focused on measures of muscle accretion and strength in response to RT. Studies published to date involving $>600$ older adults ( $>48$ years of age) show divergent results, possibly because of methodological differences across studies (Table 1 ). We have previously reviewed the majority of these studies in detail elsewhere [5,8,11-14]. Most studies $(n=16)$ involved healthy older adults, whereas 4 studies involved older adults with knee osteoarthritis, osteopenia or osteoporosis, type II diabetes, or chronic obstructive pulmonary disease (COPD). The results are equivocal regarding the efficacy of $\mathrm{CR}$ on measures of muscle accretion and strength, with half of the studies showing greater gains from CR vs. placebo (PLA) and the other half showing similar effects between the two interventions during an RT program. Individual studies typically lack adequate statistical power to detect small changes in muscle accretion and strength from CR over time, and the responsiveness to CR in older adults may be influenced by initial resting PCr levels in different muscle regions, changes in type II muscle fibre size and quantity, and habitual dietary intake of creatine [13]. To overcome the limitations of low statistical power and high variability amongst older adult populations, three meta-analyses have been performed to determine the efficacy of CR 
( $\geq 3 \mathrm{~g}$ /day) vs. PLA during an RT program ( $\geq 7$ weeks) on measures of muscle accretion and strength $[6,15,16]$. Collectively, these meta-analyses showed that the combination of CR and RT augmented muscle accretion $(\approx 1.2 \mathrm{~kg})$, and upper- and lower-body strength more than PLA and RT in older adults. Mechanistically, the greater increase in muscle accretion and strength from CR may be related to its ability to influence phosphate metabolism, calcium and glycogen regulation, cellular swelling, muscle protein signaling and breakdown, myogenic transcription factors and satellite cells, growth factors (i.e., IGF-1 and myostatin), inflammation, and oxidative stress (for reviews, see Candow et al. [5], Chilibeck et al. [6], Gualano et al. [8], and Kreider et al. [9]). Upon CR cessation, the gains in muscle accretion and strength seem to persist for up to 12 weeks when RT is maintained in older adults [17].

Table 1. Summary of studies examining creatine and resistance training on muscle outcomes in older adults.

\begin{tabular}{|c|c|c|c|c|c|}
\hline First Author, Year & Population & Supplement Dose & Resistance Training & Duration & Outcomes \\
\hline $\begin{array}{l}\text { Aguiar et al. } \\
2013[18]\end{array}$ & $\begin{array}{l}N=18 ; \text { healthy women; } \\
\quad \text { Mean age }=65 \mathrm{y}\end{array}$ & CR (5 g/day), PLA & $\mathrm{RT}=3 \mathrm{x} / \mathrm{wk}$ & $12 \mathrm{wks}$ & $\begin{array}{l}\text { CR } \uparrow \text { gains in fat-free mass } \\
(+3.2 \%) \text {, muscle mass }(+2.8 \%), 1 \\
\text { RM bench press, knee extension, } \\
\text { and biceps curl compared to PLA }\end{array}$ \\
\hline $\begin{array}{l}\text { Alves et al. } \\
2013 \text { [19] }\end{array}$ & $\begin{array}{l}N=47 ; \text { healthy women, } \\
\text { Mean age }=66.8 \text { y (range: } \\
60-80 \text { y) }\end{array}$ & $\begin{array}{l}\text { CR }(20 \mathrm{~g} / \text { day for } 5 \text { days, } \\
\text { followed by } 5 \mathrm{~g} / \text { day } \\
\text { thereafter), PLA with } \\
\text { and without RT }\end{array}$ & $\mathrm{RT}=2 \mathrm{x} / \mathrm{wk}$ & $24 \mathrm{wks}$ & $\begin{array}{c}\leftrightarrow 1 \text { RM strength compared to } \\
\text { RT + PLA }\end{array}$ \\
\hline $\begin{array}{l}\text { Bemben et al. } 2010 \\
\text { and Eliot et al. } \\
2008[20,21]\end{array}$ & $\begin{array}{c}N=42 ; \text { healthy men; } \\
\text { age }=48-72 \mathrm{y}\end{array}$ & $\begin{array}{c}\text { CR (5 g/day), PRO } \\
\text { (35 g/day) } \\
\text { CR + PRO, PLA }\end{array}$ & $\mathrm{RT}=3 \mathrm{x} / \mathrm{wk}$ & 14 wks & $\leftrightarrow$ lean tissue mass, 1 RM strength \\
\hline $\begin{array}{l}\text { Bermon et al. } \\
1998 \text { [22] }\end{array}$ & $\begin{array}{l}N=32(16 \text { men, } \\
16 \text { women); healthy; } \\
\text { age }=67-80 \mathrm{y}\end{array}$ & $\begin{array}{c}\text { CR (20 g/day for } 5 \text { days } \\
\text { followed by } \\
3 \mathrm{~g} / \text { day }), \text { PLA }\end{array}$ & $\mathrm{RT}=3 \mathrm{x} / \mathrm{wk}$ & 7.4 wks (52 days) & $\begin{array}{c}\leftrightarrow \text { lower limb muscular volume, } \\
\text { 1- and 12-repetitions maxima, } \\
\text { and isometric } \\
\text { intermittent endurance } \\
\leftrightarrow \text { muscle thickness, physical }\end{array}$ \\
\hline $\begin{array}{l}\text { Bernat et al. } \\
2019[23]\end{array}$ & $\begin{array}{l}N=24 \text { healthy men; } \\
\text { age }=59 \pm 6 y\end{array}$ & CR $(0.1 \mathrm{~g} / \mathrm{kg} /$ day $)$, PLA & $\begin{array}{l}\text { High-velocity } \\
\mathrm{RT}=2 \mathrm{x} / \mathrm{wk}\end{array}$ & $8 \mathrm{wks}$ & $\begin{array}{l}\leftrightarrow \text { muscle thickness, physical } \\
\text { performance, upper-body muscle } \\
\text { strength; CR } \uparrow \text { leg press strength, } \\
\text { total lower body strength }\end{array}$ \\
\hline $\begin{array}{l}\text { Brose et al. } \\
2003[24]\end{array}$ & $\begin{array}{c}N=28 \text { (15 men, } 13 \\
\text { women); healthy; age: } \\
\text { men }=68.7 \\
\text { women }=70.8 \mathrm{y}\end{array}$ & CR (5 g/day), PLA & $\mathrm{RT}=3 \mathrm{x} / \mathrm{wk}$ & $14 \mathrm{wks}$ & $\begin{array}{c}\mathrm{CR} \uparrow \text { gains in lean tissue mass } \\
\text { and isometric knee extension } \\
\text { strength; } \leftrightarrow \text { type } 1,2 \mathrm{a}, 2 \mathrm{x} \\
\text { muscle fibre area }\end{array}$ \\
\hline $\begin{array}{l}\text { Candow et al. } \\
2008 \text { [25] }\end{array}$ & $\begin{array}{c}N=35 ; \text { healthy men; } \\
\text { age }=59-77 \mathrm{y}\end{array}$ & $\begin{array}{c}\text { CR (0.1 g/kg/day), CR } \\
\text { + PRO (PRO: } \\
0.3 \text { g/kg/day), PLA }\end{array}$ & $\mathrm{RT}=3 \mathrm{x} / \mathrm{wk}$ & $10 \mathrm{wks}$ & $\begin{array}{c}\mathrm{CR} \uparrow \text { muscle thickness compared } \\
\text { to PLA. CR } \uparrow 1 \mathrm{RM} \text { bench press } \leftrightarrow \\
1 \mathrm{RM} \text { leg press }\end{array}$ \\
\hline $\begin{array}{l}\text { Candow et al. } \\
2015[26]\end{array}$ & $\begin{array}{l}N=39(17 \text { men, } \\
22 \text { women); healthy; } \\
\text { age }=50-71 \text { y }\end{array}$ & $\begin{array}{c}\text { CR }(0.1 \mathrm{~g} / \mathrm{kg}) \text { before RT, } \\
\text { CR }(0.1 \mathrm{~g} / \mathrm{kg}) \text { after } \\
\text { RT, PLA }\end{array}$ & $\mathrm{RT}=3 \mathrm{x} / \mathrm{wk}$ & $32 \mathrm{wks}$ & $\begin{array}{c}\text { CR after RT } \uparrow \text { lean tissue mass, } 1 \\
\text { RM leg press, } 1 \text { RM chest press } \\
\text { compared to PLA }\end{array}$ \\
\hline $\begin{array}{l}\text { Candow et al. } \\
2020[27]\end{array}$ & $\begin{array}{l}N=38 ; \text { healthy men; } \\
\text { age }=49-67 \mathrm{y}\end{array}$ & $\begin{array}{l}\text { CR (On training days: } \\
0.05 \mathrm{~g} / \mathrm{kg} \text { before and } \\
0.05 \mathrm{~g} / \mathrm{kg} \text { after exercise) } \\
+0.1 \mathrm{~g} / \mathrm{kg} / \text { day on } \\
\text { non-train-ing days } \\
\text { (2 equal doses) or PLA }\end{array}$ & $\mathrm{RT}=3 \mathrm{x} / \mathrm{wk}$ & 12 months & $\begin{array}{l}\leftrightarrow \text { lean tissue mass, muscle } \\
\text { thickness, or muscle strength }\end{array}$ \\
\hline $\begin{array}{l}\text { Chilibeck et al. } \\
2015 \text { [28] }\end{array}$ & $\begin{array}{l}N=33 ; \text { healthy women; } \\
\text { Mean age }=57 \mathrm{y}\end{array}$ & CR $(0.1 \mathrm{~g} / \mathrm{kg} /$ day $)$, PLA & $\mathrm{RT}=3 \mathrm{x} / \mathrm{wk}$ & 52 wks & $\begin{array}{c}\leftrightarrow \text { lean tissue mass and muscle } \\
\text { thickness gains between groups; } \\
\uparrow \text { relative bench press strength } \\
\text { compared to PLA. }\end{array}$ \\
\hline $\begin{array}{l}\text { Chrusch et al. } \\
2001[29]\end{array}$ & $\begin{array}{c}N=30 ; \text { healthy men; } \\
\text { age }=60-84 \text { y }\end{array}$ & $\begin{array}{c}\mathrm{CR}(0.3 \mathrm{~g} / \mathrm{kg} / \mathrm{d} \text { for } \\
5 \text { days followed by } \\
0.07 \mathrm{~g} / \mathrm{kg} / \text { day }), \text { PLA }\end{array}$ & $\mathrm{RT}=3 \mathrm{x} / \mathrm{wk}$ & $12 \mathrm{wks}$ & $\begin{array}{c}\mathrm{CR} \uparrow \text { gains in lean tissue mass; } \\
\mathrm{CR} \uparrow 1 \mathrm{RM} \text { leg press, } 1 \text { RM knee } \\
\text { extension, leg press endurance, } \\
\text { and knee extension endurance; } \\
\leftrightarrow 1 \text { RM bench press or bench } \\
\text { press endurance. }\end{array}$ \\
\hline $\begin{array}{l}\text { Cooke et al. } \\
2014[30]\end{array}$ & $\begin{array}{c}N=20 ; \text { healthy men; } \\
\text { age }=55-70 \mathrm{y}\end{array}$ & $\begin{array}{c}\text { CR (20 g/day for } 7 \text { days } \\
\text { followed by } \\
0.1 \mathrm{~g} / \mathrm{kg} / \text { day on } \\
\text { training days })\end{array}$ & $\mathrm{RT}=3 \mathrm{x} / \mathrm{wk}$ & $12 \mathrm{wks}$ & $\begin{array}{c}\leftrightarrow \text { lean tissue mass, } 1 \text { RM bench } \\
\text { press, } 1 \text { RM leg press }\end{array}$ \\
\hline $\begin{array}{l}\text { Deacon et al. } \\
2008 \text { [31] }\end{array}$ & $\begin{array}{l}N=80(50 \text { men, } \\
30 \text { women); COPD; } \\
\text { age }=68.2 \mathrm{y}\end{array}$ & $\begin{array}{l}\text { CR (22 g/day for } 5 \text { day } \\
\text { followed by } \\
3.76 \mathrm{~g} / \text { day }), \text { PLA }\end{array}$ & $\mathrm{RT}=3 \mathrm{x} / \mathrm{wk}$ & 7 wks & $\begin{array}{l}\leftrightarrow \text { lean tissue mass or } \\
\text { muscle strength }\end{array}$ \\
\hline $\begin{array}{l}\text { Eijnde et al. } \\
2003[32]\end{array}$ & $\begin{array}{c}N=46 ; \text { healthy men; } \\
\text { age }=55-75 \mathrm{y}\end{array}$ & CR (5 g/day), PLA & $\begin{array}{c}\text { Cardiorespiratory }+\mathrm{RT} \\
=2-3 \times / \mathrm{wk}\end{array}$ & $26 \mathrm{wks}$ & $\begin{array}{l}\leftrightarrow \text { lean tissue mass or isometric } \\
\text { maximal strength }\end{array}$ \\
\hline $\begin{array}{l}\text { Gualano et al. } \\
2011[33]\end{array}$ & $\begin{array}{l}N=25(9 \text { men, } 16 \text { women }) \\
\text { type } 2 \text { diabetes; age }=57 \mathrm{y}\end{array}$ & CR (5 g/day), PLA & $\mathrm{RT}=3 \mathrm{x} / \mathrm{wk}$ & 12 wks & $\leftrightarrow$ lean tissue mass \\
\hline $\begin{array}{l}\text { Gualano et al. } \\
\text { 2014 [34] }\end{array}$ & $\begin{array}{c}N=30 ; \text { "vulnera-ble" } \\
\text { women; Mean age = 65.4 y }\end{array}$ & $\begin{array}{c}\text { CR (20 g/day for } 5 \text { days; } \\
5 \text { g/day thereafter }) \\
\text { PLA with and } \\
\text { without RT }\end{array}$ & $\mathrm{RT}=2 \mathrm{x} / \mathrm{wk}$ & $24 \mathrm{wks}$ & $\begin{array}{c}\mathrm{CR}+\mathrm{RT} \uparrow \text { gains in } 1 \mathrm{RM} \text { bench } \\
\text { press and appendicular lean mass } \\
\text { compared to PLA + RT }\end{array}$ \\
\hline
\end{tabular}


Table 1. Cont.

\begin{tabular}{|c|c|c|c|c|c|}
\hline First Author, Year & Population & Supplement Dose & Resistance Training & Duration & Outcomes \\
\hline $\begin{array}{l}\text { Johannsmeyer et al. } \\
\text { 2016 [35] }\end{array}$ & $\begin{array}{c}N=31(17 \text { men, } \\
14 \text { women); healthy; } \\
\text { age }=58 \mathrm{y}\end{array}$ & CR $(0.1 \mathrm{~g} / \mathrm{kg} /$ day $)$, PLA & $\mathrm{RT}=3 \mathrm{x} / \mathrm{wk}$ & $12 \mathrm{wks}$ & $\begin{array}{c}\mathrm{CR} \uparrow \text { gains in lean tissue mass; } \leftrightarrow \\
1 \mathrm{RM} \text { strength and endurance; } \mathrm{CR} \\
\text { attenuated magnitude increase in } \\
\text { time to complete balance test } \\
\text { compared to PLA }\end{array}$ \\
\hline $\begin{array}{l}\text { Neves et al. } \\
2011[36]\end{array}$ & $\begin{array}{c}N=24 \text { (postmen-opausal } \\
\text { women with Knee } \\
\text { osteo-arthritis); } \\
\text { Age }=55-65 \mathrm{y}\end{array}$ & $\begin{array}{c}\text { CR }(20 \mathrm{~g} / \text { day for } \\
1 \text { week, followed by } \\
5 \mathrm{~g} / \text { day }), \text { PLA }\end{array}$ & $\mathrm{RT}=3 \mathrm{x} / \mathrm{wk}$ & $12 \mathrm{wks}$ & $\begin{array}{c}\mathrm{CR} \uparrow \text { gains in limb lean mass. } \leftrightarrow \\
1 \mathrm{RM} \text { leg press }\end{array}$ \\
\hline $\begin{array}{l}\text { Pinto et al. } \\
2016[37]\end{array}$ & $\begin{array}{c}N=27 \text { (men and women); } \\
\text { healthy; age }=60-80 \mathrm{y}\end{array}$ & CR (5 g/day), PLA & $\mathrm{RT}=3 \mathrm{x} / \mathrm{wk}$ & 12 wks & $\begin{array}{c}\mathrm{CR} \uparrow \text { gains in lean tissue mass; } \leftrightarrow \\
10 \mathrm{RM} \text { bench press or leg } \\
\text { press strength }\end{array}$ \\
\hline $\begin{array}{l}\text { Smolarek et al. } \\
2020[38]\end{array}$ & $\begin{array}{c}N=26 \text { ( } 5 \text { men, } 21 \text { women }) \\
\text { long-term care residence; } \\
\text { age }=68.9 \pm 6.8 \mathrm{y}\end{array}$ & CR (5 g/day), PLA & $\mathrm{RT}=2 \mathrm{x} / \mathrm{wk}$ & $16 \mathrm{wks}$ & $\begin{array}{l}\mathrm{CR} \uparrow \text { dominant and } \\
\text { non-dominant handgrip strength }\end{array}$ \\
\hline
\end{tabular}

$\mathrm{CR}=$ creatine; $\mathrm{PRO}=$ protein; $\mathrm{RM}=$ repetition maximum; $\uparrow=$ significant greater; $\leftrightarrow$ no difference between conditions; wk = weeks; $\mathrm{y}=$ years; $\mathrm{g}=$ grams; $\mathrm{kg}$ = kilograms.

Only three studies have determined the effects of CR and RT in older adults with different classifications of sarcopenia. Pinto et al. [37] showed that, in older adults with either probable sarcopenia $(n=3$; skeletal muscle mass index (SMI): appendicular skeletal muscle mass / height $2<7.26 \mathrm{~kg} / \mathrm{m}^{2}$ for men and $<5.45 \mathrm{~kg} / \mathrm{m}^{2}$ for women), sarcopenia ( $n=1$; SMI + handgrip strength $<30 \mathrm{~kg}$ and $<20 \mathrm{~kg}$ for women or gait speed $<0.8 \mathrm{~m} / \mathrm{s}$ ), or severe sarcopenia $(n=1$; SMI + handgrip strength $<30 \mathrm{~kg}$ and $<20 \mathrm{~kg}$ for women and gait speed $<0.8 \mathrm{~m} / \mathrm{s}), 12$ weeks of CR ( $5 \mathrm{~g} /$ day) and supervised RT eliminated the probable and severe sarcopenia designations in 3 participants. However, creatine had no effect on the individual with sarcopenia. Furthermore, it is unknown whether creatine and RT reduced the level of severe sarcopenia to sarcopenia or probable sarcopenia. In seven older adults considered to be pre-sarcopenic (defined as relative skeletal muscle index $>7.26 \mathrm{~kg} / \mathrm{m}^{2}$ for men and $>5.5 \mathrm{~kg} / \mathrm{m}^{2}$ for women [39]), 8 months of CR $(0.1 \mathrm{~g} / \mathrm{kg} /$ day or $\approx 8 \mathrm{~g} /$ day $)$ and supervised whole-body RT eliminated the pre-sarcopenic designation in 5 of the participants [26].

Finally, in four postmenopausal women (>60 years) who were sarcopenic (defined by appendicular lean mass, adjusted for height and weight [40]), CR (20 g/day for 5 days + $5 \mathrm{~g} /$ day for 23 weeks) during supervised whole-body RT ( 3 sets of 8-12 repetitions, 2 days per week) eliminated the sarcopenia classification in two of the women [34]. While limited by very low sample sizes, these preliminary results across studies suggest that $C R(\geq 5 \mathrm{~g} /$ day $)$ and supervised RT (>12 weeks) has some potential to mitigate sarcopenia in older adults.

Regarding physical performance (functionality), two meta-analyses of older adults demonstrated that $\mathrm{CR}$ in conjunction with RT resulted in greater improvements in sit-tostand performance when compared to RT (plus PLA) alone [5,16]. These findings are of clinical relevance given that improving sit-to-stand performance may reduce the risk of falls in older adults [41].

Independent of RT, research is mixed regarding the effectiveness of $\mathrm{CR}$ on aging muscle, with 5 studies showing greater effects from CR vs. PLA and 5 studies showing similar effects between the two interventions (for review, see Forbes et al. [42]). While it is difficult to compare results across studies, these inconsistent findings may be related to the $\mathrm{CR}$ protocol and / or dosage used. The majority of studies that found beneficial effects from CR incorporated a CR loading phase ( $20 \mathrm{~g}$ /day) or used a high relative daily dosage of creatine $(0.3 \mathrm{~g} / \mathrm{kg} /$ day $)$, whereas several of the studies that failed to observe beneficial effects did not use these strategies.

In summary, CR ( $\geq 3 \mathrm{~g} /$ day) and RT ( $\geq 7$ weeks; primarily whole-body routines) can improve some measures of muscle accretion, strength, and physical performance in older adults. Independent of RT, a CR loading phase and/or high relative daily dosage of creatine ( $\geq 0.3 \mathrm{~g} / \mathrm{kg} /$ day) may be required to produce some muscle benefits in older adults. It is unknown whether the combination of $\mathrm{CR}$ and RT provides greater fitness benefits compared to $\mathrm{CR}$ alone. Furthermore, the effects of $\mathrm{CR}$ in sarcopenic older adults is relatively unknown. No research exists regarding the efficacy of CR in older adults 
with inborn creatine synthesis deficiencies involving arginine-glycine amidinotransferase (AGAT), guanidinoacetate methyl transferase (GAMT), solute carrier 6 (SLC6AB), or CT1 (creatine transporter). Future research should investigate the effects of $C R$, with and without RT, in older clinical populations with possible musculoskeletal disorders and creatine synthesis/transporter deficiencies.

\section{Potential of Creatine Supplementation for Osteoporosis}

Osteoporosis refers to age-related loss of bone mineral density (BMD) and architecture [43] that increases bone fragility and the risks of falls and fractures [44]. There are 8 published studies that have examined the combined effects of CR and RT on properties of bone in older adults, with only 3 of these studies showing greater effects from creatine compared to PLA (Table 2). In healthy older men, 12 weeks of CR (loading phase: $0.3 \mathrm{~g} / \mathrm{kg} /$ day for 5 days; maintenance phase: $0.07 \mathrm{~g} / \mathrm{kg} /$ day for an additional 79 days) and supervised whole-body RT increased upper-limb bone mineral content (assessed by dual energy X-ray absorptiometry [DXA]) compared to PLA [45]. Additional work in healthy older men showed that 10 weeks of CR $(0.1 \mathrm{~g} / \mathrm{kg} /$ day $)$ and supervised whole-body RT decreased the urinary excretion of cross-linked $\mathrm{N}$-telopeptides of type I collagen (indicator of bone resorption) compared to PLA [25]). Most recently, Chilibeck et al. [28] showed that CR $(0.1 \mathrm{~g} / \mathrm{kg} /$ day $)$ and supervised whole-body RT for 52 weeks attenuated the rate of bone mineral loss in the femoral neck (assessed by DXA) (Figure 1) and increased femoral shaft subperiosteal width (indicator of bone bending strength) in postmenopausal women compared to PLA.

Table 2. Study characteristics and outcomes of research examining the influence of creatine with a resistance training program on bone.

\begin{tabular}{|c|c|c|c|c|}
\hline First Author, Year & Study Population & Intervention & Duration & Outcomes \\
\hline Brose et al. 2003 [24] & $\begin{array}{c}N=28 ; \text { healthy }(15 \text { men, } \\
13 \text { women); age } \geq 65 \mathrm{y} \\
\text { (men }=68.7 \mathrm{y} \text { women }=70.8 \mathrm{y} \text { ) }\end{array}$ & $\begin{array}{c}\text { RCT; CR + RT, PLA + RT. CR }= \\
5 \mathrm{~g} / \text { day; RT }=3 \mathrm{x} / \mathrm{wk}\end{array}$ & 14 wks & $\leftrightarrow$ on osteocalcin \\
\hline Candow et al. 2008 [25] & $N=35 ;$ older men (age: 59-77 y) & $\begin{array}{c}\mathrm{RCT} ; \mathrm{CR}+\mathrm{PRO}+\mathrm{RT} ; \mathrm{CR}+\mathrm{RT} \\
\mathrm{PLA}+\mathrm{RT} ; \mathrm{CR}=0.1 \mathrm{~g} / \mathrm{kg} / \text { day } \\
\mathrm{RT}=3 \times / \mathrm{wk}\end{array}$ & 10 wks & $\mathrm{CR} \downarrow$ NTx \\
\hline Candow et al. 2019 [5] & $\begin{array}{l}N=39 ; \text { healthy (17 men; } \\
22 \text { women); age } \geq 50 \text { y } \\
\text { (mean } \sim 55 \mathrm{y})\end{array}$ & $\begin{array}{c}\text { RCT; CR-Before + RT, CR-After + } \\
\text { RT, PLA + RT; CR =0.1 g/kg/day; } \\
\text { RT }=3 x / \text { wk }\end{array}$ & $8 \mathrm{mths}$ & $\begin{array}{c}\leftrightarrow \text { BMD and BMC of the whole-body, } \\
\text { limbs, femoral neck, lumbar spine, } \\
\text { and total hip }\end{array}$ \\
\hline Candow et al. 2020 [27] & $N=38 ;$ healthy men; age $=49-67 \mathrm{y}$ & $\begin{array}{c}\mathrm{RCT} ; \mathrm{CR}+\mathrm{RT}, \mathrm{PLA}+\mathrm{RT} ; \mathrm{CR}= \\
0.1 \mathrm{~g} / \mathrm{kg} / \text { day } ; \mathrm{RT}=3 \mathrm{x} / \mathrm{wk}\end{array}$ & $12 \mathrm{mths}$ & $\begin{array}{c}\leftrightarrow \text { BMD and geometry, bone speed } \\
\text { of sound; CR } \uparrow(p=0.06) \text { section } \\
\text { modulus of the narrow part of the } \\
\text { femoral neck }\end{array}$ \\
\hline Chilibeck et al. 2005 [45] & $N=29 ;$ older men $(71 \mathrm{y})$ & $\begin{array}{c}\mathrm{RCT} ; \mathrm{CR}+\mathrm{RT}, \mathrm{PLA}+\mathrm{RT} ; \mathrm{CR}= \\
0.3 \mathrm{~g} / \mathrm{kg} / \text { day for } 5 \text { days followed } \\
\text { by } 0.07 \mathrm{~g} / \mathrm{kg} / \text { day for the } \\
\text { remaining; RT }=3 \mathrm{x} / \mathrm{wk}\end{array}$ & 12 wks & $\begin{array}{l}\uparrow \text { arm BMC greater in the CR group } \\
\text { com-pared to PLA; } \leftrightarrow \text { between } \\
\text { groups for whole-body and leg BMD }\end{array}$ \\
\hline Chilibeck et al. 2015 [28] & $\begin{array}{c}N=33 \text {; postmenopausal women; } \\
\text { age: } 57 \pm 6 \text { y }\end{array}$ & $\begin{array}{c}\text { RCT; PLA + RT, CR + RT; CR = } \\
0.1 \mathrm{~g} / \mathrm{kg} / \text { day }(0.05 \mathrm{~g} / \mathrm{kg} \text { provided } \\
\text { immediately before and } 0.05 \mathrm{~g} / \mathrm{kg} \\
\text { after training on training days and } \\
\text { with two meals on non-training } \\
\text { days); RT }=3 \mathrm{x} / \mathrm{wk}\end{array}$ & 12 mths & $\begin{array}{l}\text { CR attenuated rate of femoral neck } \\
\text { BMD loss compared to PLA and CR } \\
\uparrow \text { femoral shaft subperiosteal width; } \\
\leftrightarrow \text { between groups on all other } \\
\text { outcome measures }\end{array}$ \\
\hline Gualano et al. 2014 [34] & $\begin{array}{c}N=60 \text {; older vulnerable women } \\
\text { (age: } 66 \mathrm{y})\end{array}$ & $\begin{array}{c}\text { RCT; PLA, CR, PLA + RT, CR + RT; } \\
\text { CR }=20 \mathrm{~g} / \text { day for } 5 \text { days followed } \\
\text { by } 5 \mathrm{~g} / \text { day for the remaining; RT } \\
=2 \mathrm{x} / \mathrm{wk}\end{array}$ & 24 wks & $\begin{array}{l}\leftrightarrow \text { bone mineral and serum bone } \\
\text { markers between groups }\end{array}$ \\
\hline Pinto et al. 2016 [37] & $\begin{array}{l}N=32 \text {; healthy, non-athletic men } \\
\text { and women between } 60-80 \mathrm{y}\end{array}$ & $\begin{array}{c}\text { RCT; PLA + RT, CR + RT; CR = } \\
5 \mathrm{~g} / \text { day; RT }=3 \mathrm{x} / \text { wk. Muscle } \\
\text { groups (i.e., upper and lower } \\
\text { body) alternated between training } \\
\text { days, } 1.5 \mathrm{x} / \text { wk per muscle group }\end{array}$ & 12 wks & $\begin{array}{c}\leftrightarrow \mathrm{BMD} \text { and BMC of all assessed } \\
\text { sites between groups }\end{array}$ \\
\hline
\end{tabular}

$\mathrm{RCT}$ = randomized controlled trial; $\mathrm{PLA}=$ placebo; $\mathrm{RT}=$ resistance training; $\mathrm{CR}=$ creatine; $\mathrm{PRO}=$ protein; $\mathrm{RM}=$ repetition maximum; $\mathrm{NTx}=$ cross-linked $\mathrm{N}$-telopeptides of type I collagen; $\mathrm{BMD}=$ bone mineral density; $\mathrm{BMC}=$ bone mineral content; $\uparrow=$ significant greater; $\leftrightarrow$ no difference be-tween conditions; $\mathrm{wk}=$ weeks; $\mathrm{mth}=$ months; $\mathrm{y}=$ years; $\mathrm{g}=$ grams; $\mathrm{kg}=$ kilograms. 


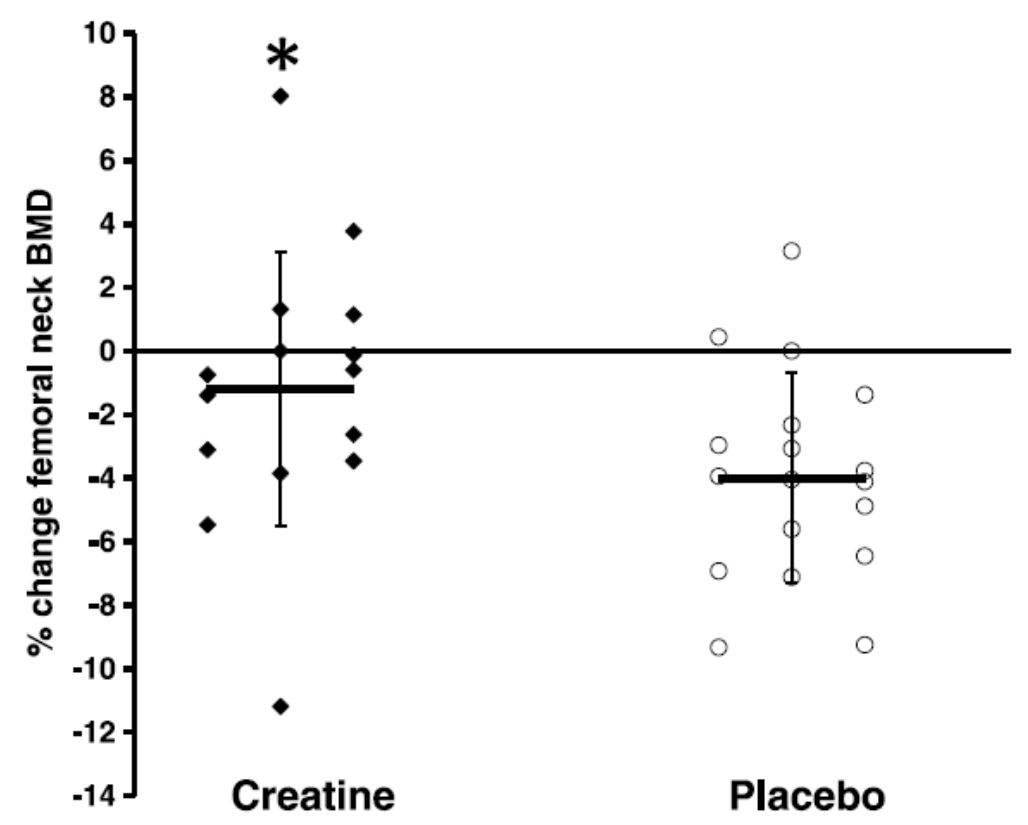

Figure 1. Relative changes in femoral neck bone mineral density (BMD). "Closed diamonds" represent changes for individual creatine group participants, and "open circles" represent placebo group participants. The "horizontal bars" represent the group means, and the "vertical bars" represent the SD. * Creatine participants lost significantly less BMD at the femoral neck compared with placebo participants $(p<0.05)$. (Reproduced with permission from Chilibeck et al. 2015 [28]).

In contrast to these studies, Brose et al. [24] was unable to find a beneficial effect from 14 weeks of CR ( $5 \mathrm{~g} /$ day) and whole-body RT on serum osteocalcin (indicator of bone formation) compared to PLA in healthy older adults. Furthermore, Gualano et al. [34] found no effect from CR (loading phase: $20 \mathrm{~g}$ /day for 5 days; maintenance phase: $5 \mathrm{~g} /$ day for an additional 24 weeks) and supervised whole-body RT on changes in bone mineral (density and content; assessed by DXA) or serum concentrations of procollagen type 1 N-propeptide (P1NP; indicator of bone formation) and type 1 collagen C-telopeptide (CTX; indicator of bone resorption) compared to PLA in older women. In addition, 12 weeks of CR ( $5 \mathrm{~g}$ /day) and supervised whole-body RT had no greater effect on measures of BMD or content (assessed by DXA) compared to PLA in healthy older adults [37]. Similarly, Candow et al. [46] was unable to find greater effects from CR $(0.1 \mathrm{~g} / \mathrm{kg} /$ day $)$ and 32 weeks of supervised whole-body RT on measures of bone mineral (density and content; assessed by DXA) compared to PLA in healthy older adults. Most recently, Candow et al. [27] failed to show a beneficial effect from 52 weeks of CR $(0.1 \mathrm{~g} / \mathrm{kg} /$ day $)$ and supervised whole-body RT on measures of BMD or bone geometric properties (assessed by DXA and ultrasound) in older men compared to PLA.

There are only three studies that have investigated the effects of CR alone (no exercise training stimulus) on properties of aging bone. In postmenopausal women with osteopenia or osteoporosis, 24 weeks of CR (loading phase: $20 \mathrm{~g}$ /day for 5 days; maintenance phase: $5 \mathrm{~g}$ /day for an additional 23 weeks) had no effect on measures of BMD (whole-body, lumbar, total femur, and femoral neck; assessed by DXA) or serum markers of bone turnover (CTX, P1NP) compared to PLA [34]. In two additional studies involving postmenopausal women, CR ( $1 \mathrm{~g} /$ day for 52 weeks) had no effect on measures of BMD (assessed by DXA), bone microarchitecture (assessed by high-resolution peripheral quantitative computed tomography (HR-pQCT)), CTX, or P1NP compared to PLA [47]. Increasing the dosage of creatine to $3 \mathrm{~g}$ /day for an additional 52 weeks (104 weeks in total) also had no effect on the same bone measures in postmenopausal women. Furthermore, creatine had no effect on the number of falls or fractures experienced [48].

Collectively, the vast majority of studies show no greater effect from $C R$, with and without RT, on properties of bone in older adults. In the few studies that did show beneficial 
effects, CR was combined with supervised whole-body RT. Importantly, no study showed any detrimental effect from CR on bone mineral or geometry. The combined effects of CR and RT on reducing the risk and incidence of falls and fractures in older adults is largely unknown. Bone tissue typically takes a long time (i.e., several months) to turnover [49], especially in older adults [50]. Future research should investigate the longer-term effects (i.e., $\geq 2$ years) of $\mathrm{CR}$, with and without $\mathrm{RT}$, on properties of bone mineral and geometry and risk of falls and fractures in older adults.

\section{Potential of Creatine Supplementation for Osteosarcopenia}

Osteosarcopenia is a musculoskeletal syndrome characterized by low BMD (osteopenia/osteoporosis) and muscle mass and function (sarcopenia) and is predictive of functional impairments, falls, fractures, and premature mortality in older adults [51]. Despite recent commentary proposing the use of CR to combat age-related muscle and bone loss [52,53], no randomized controlled trial (RCT) has tested the effects of creatine versus PLA (control) in osteosarcopenic adults [54]. Nevertheless, there is potential for CR, with and without RT, to be used as an upstream prevention or downstream treatment strategy for this age-related debilitating syndrome.

Creatine may directly or indirectly impact components of osteosarcopenia (muscle mass, bone density, and function) via its actions on muscle and bone metabolism. In skeletal muscle, creatine is capable of upregulating anabolic signaling pathways, increasing satellite cell number/content and growth factors, as well as downregulating markers of inflammation and oxidative stress $[5,6,8,9]$. Creatine's role is not exclusive to muscle tissue, with preclinical studies showing that creatine may promote the differentiation of osteoblast cells involved in bone formation [55,56]. Despite this, in the absence of RT, findings from mechanistic studies involving CR have largely failed to translate into clinical improvements in musculoskeletal outcomes in healthy older adults. As highlighted previously, experimental trials have shown significant heterogeneity in study methodology, which likely relates to the inconsistent findings (see Tables 1 and 2).

Of note, 2 years of CR ( $3 \mathrm{~g} /$ day) without RT did not influence bone density/micro architecture, bone turnover markers, lean mass and muscle strength/function, or falls and fractures in postmenopausal women with osteopenia [48]. However, these participants were not sarcopenic or osteosarcopenic and the RCT was not powered to detect the effects of creatine on falls and fractures, which were considerably low throughout the trial [48]. Importantly, the authors did not rule out the possible benefits of CR in conjunction with RT.

It is somewhat surprising that no RCT exists in osteosarcopenic individuals despite the well-established biomechanical and biochemical connection between muscle and bone [57]. Indeed, skeletal muscle acts as a pulley and bone as a lever during human movement and the forces applied to myofibres during RT are transmitted to bone to initiate osteocyteinduced bone formation [57], and during inactivity, the opposite occurs, leading to degeneration of both tissues. This biomechanical interaction during activity (or lack of during inactivity) occurs alongside biochemical cross-talk via hormones and other growth factors secreted by muscle and bone cells [57]. Given that lean (muscle) mass is a major predictor of BMD [58] that and osteopenia/osteoporosis increases the risk of sarcopenia (the opposite is also true) [59], it is possible that creatine's anabolic effect on skeletal muscle may indirectly promote bone accretion and geometry. For instance, CR increases insulin-like growth factor I (IGF-1) content [60] and downregulates myostatin levels [61,62], and the former initiates osteoblastogenesis (bone formation) while the latter initiates osteoclastogenesis (bone resorption) [57]. Thus, aside from the mechanical interaction, cross-talk between muscle and bone cells represents another feasible avenue by which CR has the potential to combat osteosarcopenia. To test this hypothesis, future mechanistic studies should examine the effects of CR on hormonal factors released by the endocrine system in addition to growth factors (osteokines and myokines) secreted by muscle and bone cells. Furthermore, in order to determine the efficacy and safety of CR in older osteosarcopenic adults, future RCTs should include measures of both muscle and bone (muscle mass, strength, physical 
function, bone structure, and bone biomarkers) as well as clinically relevant outcomes on activities of daily living, falls, and fractures. It is also important that vital signs and adverse events are recorded in future RCTs involving creatine dosages, both of which are not consistently monitored or reported on in exercise/nutritional trials [63]. Given that adaptions in muscle mass and cortical/trabecular bone may take at least 6 months to be radiographically detected following anabolic stimuli (i.e., RT) in older osteosarcopenic adults [54], CR protocols should at least match or exceed this duration. Finally, as poor nutritional status is a risk factor for osteosarcopenia [52,53,64], the possible interaction of creatine with other essential nutrients capable of modulating muscle and bone metabolism such protein, vitamin D, and calcium [64] should be explored. Providing this information is of clinical relevance as creatine, with or without RT, may be a cost-effective strategy to treat older adults with or at risk of osteosarcopenia.

\section{Potential of Creatine Supplementation for Sarcopenic Obesity}

Sarcopenia has a negative effect on mobility, energy expenditure, and metabolic health, which subsequently increases adipose tissue accumulation (i.e., obesity [65]), especially in and around skeletal muscle [66]. Sarcopenic obesity (SO) occurs in approximately $20 \%$ of older adult populations [67] and increases the risk of cardiometabolic diseases, osteoporosis, disability, and premature mortality (for review, see Roh and Choi [68]). Similar to sarcopenia, there is no unanimous definition of SO. The WHO classifies obesity as a body mass index (BMI) $\geq 30 \mathrm{~kg} / \mathrm{m}^{2}$. However, individuals of east Asian descent have elevated body fat \% compared to non-Asians with an equivalent BMI [69]; thus, east Asian's have a lower BMI cutoff point for obesity $\left(\geq 25 \mathrm{~kg} / \mathrm{m}^{2}\right)$. Beyond BMI, body fat distribution (i.e., waist circumference) enhances the ability to predict the development of metabolic syndrome and risk of cardiovascular disease [70], with the WHO indicating cutoff values of $\geq 102 \mathrm{~cm}$ for men and $\geq 88 \mathrm{~cm}$ for women, which differ for Asian populations [71,72]. Further, the American Association of Clinical Endocrinology [73] classifies obesity using body fat thresholds of $>25 \%$ in men and $>35 \%$ in women. Due to the lack of a universally accepted definition, the prevalence of SO varies. For example, in a prospective study of older adults ( $n=4652 ;>60$ years of age), the prevalence of sarcopenic obesity was $18.1 \%$ in women and $42.9 \%$ in men [74].

A recent systematic review and meta-analysis of 19 studies involving older adults ( $n=609$ participants; $\geq 50$ years of age) showed that the combination of CR and RT resulted in a greater reduction in fat mass $(0.5 \mathrm{~kg}, p=0.13)$ and body fat $\%(0.55 \%, p=0.04)$ compared to PLA and RT [75]. Mechanistically, creatine appears to also influence adipose tissue biology. In multiple adipogenic cell culture models, creatine attenuated the accumulation of cytoplasmic triglycerides in a dose-dependent manner through inhibition of phosphatidylinositol 3-kinase activation [76]. There is also evidence that creatine can alter whole-body energetics and expenditure [77]. In rodents, diminishing creatine content impaired thermal homeostasis [78] and deletion of glycine amidinotransferase (the rate limiting enzyme of creatine synthesis) attenuated creatine content in brown adipose and impaired thermoregulation $[77,79]$, which subsequently attenuated the capacity to activate diet-induced thermogenesis, resulting in increased adiposity [79]. Furthermore, global creatine transporter (Slc6a8) knockout mice presented with greater body fat stores compared to controls [80] possibly due to lower whole-body energy expenditure, a decrease in oxidative metabolism in beige and brown adipose tissue, and an increase in feed efficiency [81].

Collectively, CR and RT appear to be an effective intervention for decreasing body fat $\%$ in older adults. However, the effects of CR alone on adipose tissue biology in older adults are unknown. Furthermore, it remains to be determined whether CR, with and without RT or other exercise-training modalities (i.e., aerobic), can overcome SO. Based on the potential interaction of muscle and fat tissue and mechanistic actions of creatine on adipogenesis and whole-body energy expenditure, future research is warranted and may be of clinical importance for older adults. 


\section{Potential of Creatine Supplementation for Physical Frailty}

Frailty is defined as a syndrome of physiological decline in later life, characterized by vulnerability to adverse health outcomes (i.e., hospitalization, falls, social isolation, and reduced quality of life (QoL)) [82-84]. Frailty is commonly defined according to the phenotype of physical frailty proposed by Fried et al. [82], which consists of weakness, slowness, low levels of physical activity, shrinking, and exhaustion, with one or two criteria indicating a prefrailty stage and three or more marking frailty. A recent study in a combined cohort of 8804 Australian adults aged $\geq 65$ years (women $86 \%$, median age 80 years) found that, while $21 \%$ of participants were frail, a staggering $48 \%$ were prefrail [85]. With the aging population and growing incidence of prefrail older adults progressing to frailty every year (at a rate of $11 \%$ ), the incidence of adverse health outcomes represents a substantial burden on total healthcare costs worldwide.

Due to the predominantly musculoskeletal and physical components of the frailty phenotype, there is an unavoidable overlap between sarcopenia, osteosarcopenia, and physical frailty [86]. Regarding their common pathophysiology, these conditions share immune, endocrine, and inflammatory mechanisms, which could be targeted via nonpharmacological interventions such as exercise and nutrition (i.e., creatine) [64,87]. However, research is very limited regarding $\mathrm{CR}$ and physical frailty. Although some studies testing CR have involved older adults that could fulfil the clinical phenotype, those participants are usually labelled as healthy or non-sarcopenic. In the only clinical trial to directly assess the effects of CR in mildly frail older adults (defined as those with limited dependence on others for instrumental activities of daily living according to the Canadian Study of Health and Aging clinical frailty scale [88], Collins et al. [89] found no additive effect from CR ( $5 \mathrm{~g} /$ day) to whey protein $(20 \mathrm{~g})$ and RT (14 weeks) on measures of muscle strength and functionality compared to whey protein and training alone. However, the small sample size $(n=16)$ and lack of PLA and non-training control group limits the clinical application of these preliminary findings. In addition to the effects of $\mathrm{CR}$ on muscle and bone as previously described, there is evidence that creatine may have beneficial effects on the other components of the frailty syndrome (summarized in [90]). Creatine exhibits an anti-inflammatory effect via regulation of the cyclo-oxygenase pathway and reduction of serum levels of inflammatory cytokines (i.e., tumor necrosis factor- $\alpha$ (TNF- $\alpha$ ) and IL-6), which have been associated with sarcopenia, osteoporosis, and frailty [91,92]. The small number of studies that have examined the efficacy of CR on immune system response have shown an alteration in soluble mediator production and expression of molecules involved in recognizing infections, specifically toll-like receptors. Creatine has also been proposed to be neuroprotective, an effect that could have a potential role in the treatment of the neuromuscular components of frailty [93]. Finally, creatine may act as an antioxidant, which would also benefit frail older adults susceptible to increased oxidative stress and damage [94].

In summary, despite the preclinical and clinical evidence demonstrating an effect from creatine on multiple pathophysiological mechanisms associated with frailty, no RCT has been performed examining the effects of CR (alone or in combination with exercise) in frail older adults. A major challenge in this line of research relates to the identification of frailty, which could lead to significant variability across studies. In the case of physical frailty, we propose that the adoption of Fried's criteria be used to facilitate and identify the condition through a well-accepted phenotype in which the quantification of any therapeutic effect(s) from CR can be made.

\section{Potential of Creatine Supplementation for Cachexia}

Cachexia can be defined as a tissue loss syndrome that involves severe weight loss and muscle wasting [95]. Cachexia is usually secondary to conditions such as cancer, COPD, chronic kidney disease, and heart failure, and therefore, therapeutic interventions should involve not only the prevention of muscle wasting but also appropriate treatment of the secondary cause. 
Muscle loss in cachexia is due to both reduced protein synthesis and increased catabolism (proteolysis) due to multiple factors including reduced oral intake, high levels of inflammation, tumor-mediated effects, low physical activity, and endocrine and metabolic disturbances [96]. Some studies have demonstrated that CR can have an effect on the majority of these mechanisms; however, PLA-controlled studies have shown mixed results. Most of the studies involving CR and cachexia have been performed in cancer patients (summarized in Table 3). Overall, CR failed to produce significant effects on muscle accretion, muscle performance, or functionality. However, creatine had no detrimental effect on muscle, bone, performance, or functionality and no major adverse events were reported from those taking creatine. The inconsistent findings across studies are possibly explained by low sample sizes, multifactorial nature of the condition, deleterious effect of chemotherapy on muscle, lack of exercise intervention, length and dosage of creatine used, and heterogeneity of secondary causes of cachexia.

There may be potential for cachexia patients to experience some benefits from CR and RT. For example, some subsets of cancer are characterized by high rates of weight and muscle loss (i.e., head and neck, pancreatic, lung, colorectal, and gastric cancer) [97], which may be counteracted by creatine. Additionally, CR may also be beneficial for older adults with cachexia and/or cancer undergoing treatments that negatively affect muscle and bone mass, performance, and function (i.e., androgen deprivation therapies).

In summary, cachexia is a debilitating condition associated with multiple chronic diseases, especially cancer. Creatine has the potential to target several of the mechanisms associated with cachexia; however, research investigating the effects of creatine and cachexia is very limited. Future large-scale RCT's examining the effects of creatine, with and without exercise and pharmacological therapies, are warranted and needed. 
Table 3. Studies examining Cr supplementation in a cancer context.

\begin{tabular}{|c|c|c|c|c|c|c|c|c|}
\hline Authors (Year) & Patients & Treatment Modality & Dosage & Protocol Du-RATION & Compliance & Exercise Program & Results & $\begin{array}{c}\text { Adverse Effects Related } \\
\text { to Supplementation }\end{array}$ \\
\hline Jatoi et al. (2017) [98] & $\begin{array}{c}263 \text { cancer patients } \\
(65 \pm 11 \text { yrs.) with weight } \\
\text { loss syndrome }\end{array}$ & $\begin{array}{l}210 \text { undergoing concurrent } \\
\text { chemotherapy }\end{array}$ & $\begin{array}{l}20 \mathrm{~g} / \text { day for } 5 \text { days } \\
\text { then } 2 \mathrm{~g} / \text { day }\end{array}$ & 39 weeks & $\mathrm{nr}$ & $\mathrm{n} / \mathrm{a}$ & $\begin{array}{l}\leftrightarrow \text { body weight, } \\
\text { appetite, QoL, frailty, } \\
\text { grip strength }\end{array}$ & None reported \\
\hline $\begin{array}{l}\text { Bourgeois et al. } \\
\text { (2008) [99] }\end{array}$ & $\begin{array}{l}9 \text { children ( } 7.6 \pm 3.8 \text { yrs.) } \\
\text { with ALL under-going } \\
\text { chemotherapy }\end{array}$ & $\begin{array}{c}\text { Maintenance phase of } \\
\text { treatment on the } \\
\text { Dann-Farber Cancer } \\
\text { Institute protocol 2000-2001 } \\
n=11 \text { : fluorouracil/ folic }\end{array}$ & $0.1 \mathrm{~g} / \mathrm{kg} /$ day & $\begin{array}{c}2 \times 16 \text { weeks separated } \\
\text { by } 6 \text {-week wash-out } \\
\text { period. }\end{array}$ & $\mathrm{nr}$ & $\mathrm{n} / \mathrm{a}$ & $\begin{array}{c}\downarrow \mathrm{BF} \% \mathrm{Cr}, \uparrow \mathrm{BF} \% \mathrm{NH}, \\
\leftrightarrow \mathrm{BMD}\end{array}$ & None reported \\
\hline $\begin{array}{c}\text { Norman et al. (2006) } \\
\text { [100] }\end{array}$ & $\begin{array}{c}31 \text { stage III/IV colorectal } \\
\text { cancer patients } \\
(65.10 \pm 12.55 \text { yrs.) } \\
\text { undergoing } \\
\text { chemotherapy }\end{array}$ & $\begin{array}{l}\text { acid (5-FU FA); } n=9: \\
\text { fluorouracil/folic acid + } \\
\text { oxaliplatin (5-FU FA + O); } \\
n=1 \text { 1: fluorouracil/folic } \\
\text { acid + irinotecan } \\
\text { (5-FU FA + I) }\end{array}$ & $\begin{array}{l}20 \mathrm{~g} / \text { day for } 7 \text { days } \\
\text { then } 5 \mathrm{~g} / \text { day }\end{array}$ & 8 weeks & $\begin{array}{l}\text { Cr: } 84.55 \pm 7.77 \% \\
\text { PLA: } 87.62 \pm 5.90 \%\end{array}$ & $\mathrm{n} / \mathrm{a}$ & $\begin{array}{c}\leftrightarrow \text { weight, capacitance, } \\
\text { KE, HR, BCM, BF; } \uparrow \\
\text { HG 5-FU FA: } \uparrow \text { phase } \\
\text { angle, ECM } / \text { BCM ratio }\end{array}$ & None reported \\
\hline $\begin{array}{c}\text { Lonbro et al. (2013) } \\
\text { [101] }\end{array}$ & $\begin{array}{l}30 \text { Head and neck } \\
\text { patients treated with } \\
\text { radiotherapy }\end{array}$ & $\begin{array}{l}\text { Radiotherapy according to } \\
\text { DA-HANCA guidelines } \\
\text { (www.da-hanca.dk) }+ \\
\text { chemotherapy }(n=20: \\
\left.\text { cisplatin, } 40 \mathrm{mg} / \mathrm{m}^{2}\right) . N=4 \\
\text { received Zalutumumab }\end{array}$ & $\begin{array}{c}5 \mathrm{~g} / \text { day }+30 \mathrm{~g} \\
\text { Pro/day }\end{array}$ & 12 weeks & $\begin{array}{l}69 \% \text { ingested all } \\
\text { supplementation; } \\
19 \% \text { missed } \leq 3 \\
\text { supplementations; } \\
12 \% \text { terminated } 4 \\
\text { weeks early }\end{array}$ & $\begin{array}{c}3 \text { days/wk., } \\
3 \times 10 \text { total body }\end{array}$ & $\begin{array}{c}\uparrow \text { LBM ProCr group, } \\
\text { ns PLA } \leftrightarrow \text { muscle } \\
\text { strength }{ }^{* *}, \leftrightarrow \text { Physical } \\
\text { function }{ }^{* *}\end{array}$ & $\begin{array}{c}\text { No major adverse events } \\
\text { reported; } 2 \text { participants } \\
\text { stopped supplementation } \\
4 \text { weeks early due to } \\
\text { muscle cramping and } \\
\text { mucus production }\end{array}$ \\
\hline
\end{tabular}

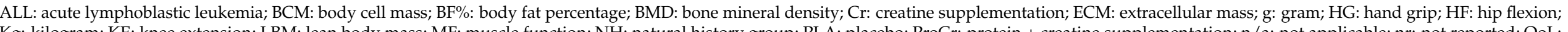

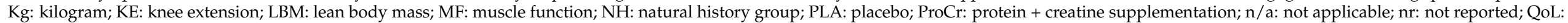

quality of life; yrs: years old; $\uparrow:$ increase; $\downarrow$ : decrease; $\leftrightarrow$ : no change; ${ }^{* *}$ compared to placebo. (Reproduced with permission from Fairman et al. 2019 [97]) 


\section{Conclusions}

Sarcopenia refers to age-related reduction in muscle mass, strength, and/or physical performance and has a negative effect on the ability to perform activities of daily living and overall quality of life. Comorbidities associated with sarcopenia include osteoporosis, osteosarcopenia, sarcopenic obesity, physical frailty, and cachexia. As a possible countermeasure to sarcopenia and its age-related co-morbidities, CR (especially when combined with RT) has some favourable effects on aging muscle, bone and fat mass, muscle and bone strength, and physical performance, primarily in healthy populations (Figure 2). Independent of RT, a CR loading phase and/or high relative daily dosage of creatine $(\geq 0.3 \mathrm{~g} / \mathrm{kg}$ ) may be required to produce some muscle benefits in older adults. CR (independent of resistance training) for up to 2 years appears to provide no bone benefits in older females. The effects of CR alone on bone measures in older males is unknown. Despite its potential, the effects of CR in older adults with sarcopenia, osteoporosis, osteosarcopenia, sarcopenic obesity, physical frailty, and cachexia remain largely unknown and warrant future long-term clinical trials involving large sample sizes.

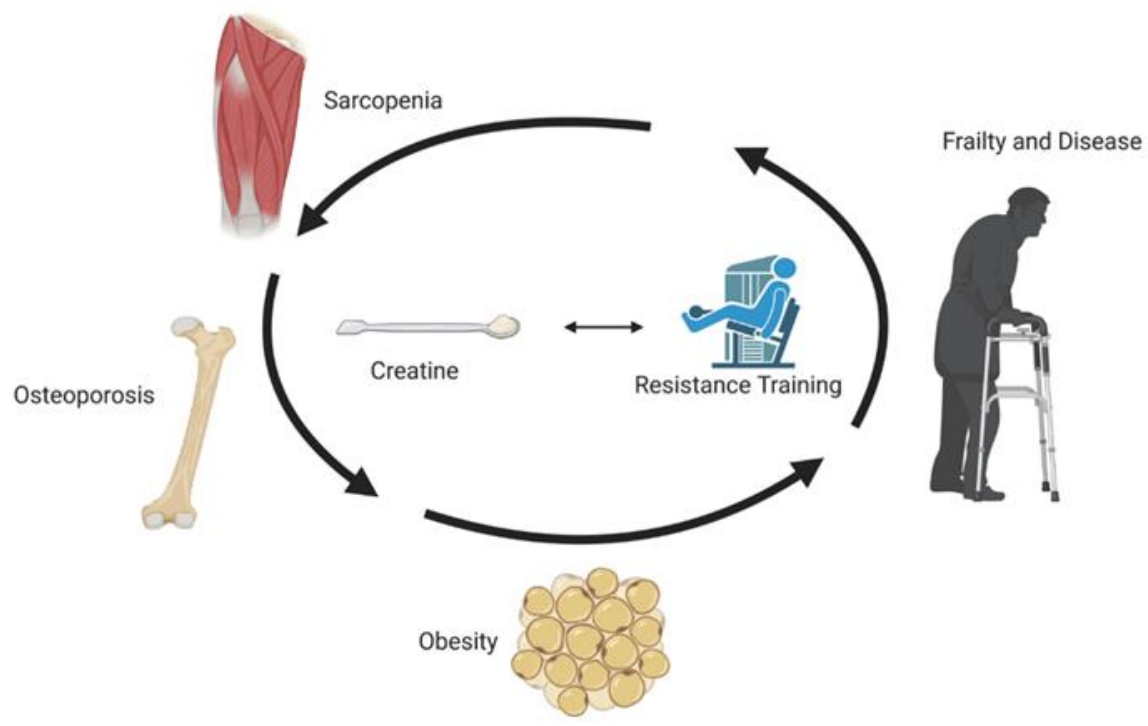

Figure 2. Potential effect of creatine, with and without resistance training.

Author Contributions: Conceptualization, D.G.C., B.K. and G.D.; writing-original draft preparation, D.G.C., S.C.F., B.K. and G.D.; writing-review and editing, D.G.C., S.C.F., B.K. and G.D. All authors have read and agreed to the published version of the manuscript.

Funding: This research received no external funding.

Conflicts of Interest: D.G.C. has conducted industry sponsored research involving creatine supplementation and received creatine donations for scientific studies and travel support for presentations involving creatine supplementation at scientific conferences. In addition, D.G.C. serves on the Scientific Advisory Board for Alzchem (a company that manufactures creatine). S.C.F. has served as a scientific advisor for a company that sells creatine products. B.K. and G.D. declare no conflicts of interest.

\section{References}

1. Cruz-Jentoft, A.J.; Bahat, G.; Bauer, J.; Boirie, Y.; Bruyere, O.; Cederholm, T.; Cooper, C.; Landi, F.; Rolland, Y.; Sayer, A.A.; et al. Writing Group for the European Working Group on Sarcopenia in Older People 2 (EWGSOP2), and the Extended Group for EWGSOP2 Sarcopenia: Revised European consensus on definition and diagnosis. Age Ageing 2019, 48, 16-31. [CrossRef]

2. Shafiee, G.; Keshtkar, A.; Soltani, A.; Ahadi, Z.; Larijani, B.; Heshmat, R. Prevalence of sarcopenia in the world: A systematic review and meta- analysis of general population studies. J. Diabetes Metab. Disord. 2017, 16, 1-10. [CrossRef]

3. Tournadre, A.; Vial, G.; Capel, F.; Soubrier, M.; Boirie, Y. Sarcopenia. Joint Bone Spine 2019, 86, 309-314. [CrossRef] 
4. Mitchell, W.K.; Williams, J.; Atherton, P.; Larvin, M.; Lund, J.; Narici, M. Sarcopenia, dynapenia, and the impact of advancing age on human skeletal muscle size and strength; a quantitative review. Front. Physiol. 2012, 3, 260. [CrossRef]

5. Candow, D.G.; Forbes, S.C.; Chilibeck, P.D.; Cornish, S.M.; Antonio, J.; Kreider, R.B. Effectiveness of Creatine Supplementation on Aging Muscle and Bone: Focus on Falls Prevention and Inflammation. J. Clin. Med. 2019, 8, 488. [CrossRef]

6. Chilibeck, P.D.; Kaviani, M.; Candow, D.G.; Zello, G.A. Effect of creatine supplementation during resistance training on lean tissue mass and muscular strength in older adults: A meta-analysis. Open Access J. Sports Med. 2017, 8, 213-226. [CrossRef]

7. Forbes, S.C.; Chilibeck, P.D.; Candow, D.G. Creatine Supplementation During Resistance Training Does Not Lead to Greater Bone Mineral Density in Older Humans: A Brief Meta-Analysis. Front. Nutr. 2018, 5, 27. [CrossRef]

8. Gualano, B.; Rawson, E.S.; Candow, D.G.; Chilibeck, P.D. Creatine supplementation in the aging population: Effects on skeletal muscle, bone and brain. Amino Acids 2016, 48, 1793-1805. [CrossRef] [PubMed]

9. Kreider, R.B.; Kalman, D.S.; Antonio, J.; Ziegenfuss, T.N.; Wildman, R.; Collins, R.; Candow, D.G.; Kleiner, S.M.; Almada, A.L.; Lopez, H.L. International Society of Sports Nutrition position stand: Safety and efficacy of creatine supplementation in exercise, sport, and medicine. J. Int. Soc. Sports Nutr. 2017, 14, 1-18. [CrossRef] [PubMed]

10. Wyss, M.; Kaddurah-Daouk, R. Creatine and creatinine metabolism. Physiol. Rev. 2000, 80, 1107-1213. [CrossRef] [PubMed]

11. Candow, D.G. Sarcopenia: Current theories and the potential beneficial effect of creatine application strategies. Biogerontology 2011, 12, 273-281. [CrossRef]

12. Candow, D.G.; Forbes, S.C.; Little, J.P.; Cornish, S.M.; Pinkoski, C.; Chilibeck, P.D. Effect of nutritional interventions and resistance exercise on aging muscle mass and strength. Biogerontology 2012, 13, 345-358. [CrossRef]

13. Candow, D.G.; Forbes, S.C.; Chilibeck, P.D.; Cornish, S.M.; Antonio, J.; Kreider, R.B. Variables Influencing the Effectiveness of Creatine Supplementation as a Therapeutic Intervention for Sarcopenia. Front. Nutr. 2019, 6, 124. [CrossRef]

14. Forbes, S.C.; Little, J.P.; Candow, D.G. Exercise and nutritional interventions for improving aging muscle health. Endocrine 2012, 42, 29-38. [CrossRef]

15. Candow, D.G.; Chilibeck, P.D.; Forbes, S.C. Creatine supplementation and aging musculoskeletal health. Endocrine 2014, 45, 354-361. [CrossRef] [PubMed]

16. Devries, M.C.; Phillips, S.M. Creatine supplementation during resistance training in older adults-a meta-analysis. Med. Sci. Sports Exerc. 2014, 46, 1194-1203. [CrossRef] [PubMed]

17. Candow, D.G.; Chilibeck, P.D.; Chad, K.E.; Chrusch, M.J.; Davison, K.S.; Burke, D.G. Effect of ceasing creatine supplementation while maintaining resistance training in older men. J. Aging Phys. Act. 2004, 12, 219-231. [CrossRef] [PubMed]

18. Aguiar, A.F.; Januario, R.S.; Junior, R.P.; Gerage, A.M.; Pina, F.L.; do Nascimento, M.A.; Padovani, C.R.; Cyrino, E.S. Long-term creatine supplementation improves muscular performance during resistance training in older women. Eur. J. Appl. Physiol. 2013, 113, 987-996. [CrossRef]

19. Alves, C.R.; Merege Filho, C.A.; Benatti, F.B.; Brucki, S.; Pereira, R.M.; de Sa Pinto, A.L.; Lima, F.R.; Roschel, H.; Gualano, B. Creatine supplementation associated or not with strength training upon emotional and cognitive measures in older women: A randomized double-blind study. PLoS ONE 2013, 8, e76301. [CrossRef]

20. Bemben, M.G.; Witten, M.S.; Carter, J.M.; Eliot, K.A.; Knehans, A.W.; Bemben, D.A. The effects of supplementation with creatine and protein on muscle strength following a traditional resistance training program in middle-aged and older men. J. Nutr. Health Aging 2010, 14, 155-159. [CrossRef]

21. Eliot, K.A.; Knehans, A.W.; Bemben, D.A.; Witten, M.S.; Carter, J.; Bemben, M.G. The effects of creatine and whey protein supplementation on body composition in men aged 48 to 72 years during resistance training. J. Nutr. Health Aging 2008, 12, 208-212. [CrossRef]

22. Bermon, S.; Venembre, P.; Sachet, C.; Valour, S.; Dolisi, C. Effects of creatine monohydrate ingestion in sedentary and weighttrained older adults. Acta Physiol. Scand. 1998, 164, 147-155. [CrossRef]

23. Bernat, P.; Candow, D.G.; Gryzb, K.; Butchart, S.; Schoenfeld, B.J.; Bruno, P. Effects of high-velocity resistance training and creatine supplementation in untrained healthy aging males. Appl. Physiol. Nutr. Metab. 2019, 44, 1246-1253. [CrossRef] [PubMed]

24. Brose, A.; Parise, G.; Tarnopolsky, M.A. Creatine supplementation enhances isometric strength and body composition improvements following strength exercise training in older adults. J. Gerontol. A Biol. Sci. Med. Sci. 2003, 58, 11-19. [CrossRef]

25. Candow, D.G.; Little, J.P.; Chilibeck, P.D.; Abeysekara, S.; Zello, G.A.; Kazachkov, M.; Cornish, S.M.; Yu, P.H. Low-dose creatine combined with protein during resistance training in older men. Med. Sci. Sports Exerc. 2008, 40, 1645-1652. [CrossRef]

26. Candow, D.G.; Vogt, E.; Johannsmeyer, S.; Forbes, S.C.; Farthing, J.P. Strategic creatine supplementation and resistance training in healthy older adults. Appl. Physiol. Nutr. Metab. 2015, 40, 689-694. [CrossRef]

27. Candow, D.G.; Chilibeck, P.D.; Gordon, J.; Vogt, E.; Landeryou, T.; Kaviani, M.; Paus-Jensen, L. Effect of 12 months of creatine supplementation and whole-body resistance training on measures of bone, muscle and strength in older males. Nutr. Health 2020, 260106020975247. [CrossRef]

28. Chilibeck, P.D.; Candow, D.G.; Landeryou, T.; Kaviani, M.; Paus-Jenssen, L. Effects of Creatine and Resistance Training on Bone Health in Postmenopausal Women. Med. Sci. Sports Exerc. 2015, 47, 1587-1595. [CrossRef] [PubMed]

29. Chrusch, M.J.; Chilibeck, P.D.; Chad, K.E.; Davison, K.S.; Burke, D.G. Creatine supplementation combined with resistance training in older men. Med. Sci. Sports Exerc. 2001, 33, 2111-2117. [CrossRef] 
30. Cooke, M.B.; Brabham, B.; Buford, T.W.; Shelmadine, B.D.; McPheeters, M.; Hudson, G.M.; Stathis, C.; Greenwood, M.; Kreider, R.; Willoughby, D.S. Creatine supplementation post-exercise does not enhance training-induced adaptations in middle to older aged males. Eur. J. Appl. Physiol. 2014, 114, 1321-1332. [CrossRef] [PubMed]

31. Deacon, S.J.; Vincent, E.E.; Greenhaff, P.L.; Fox, J.; Steiner, M.C.; Singh, S.J.; Morgan, M.D. Randomized controlled trial of dietary creatine as an adjunct therapy to physical training in chronic obstructive pulmonary disease. Am. J. Respir. Crit. Care Med. 2008, 178, 233-239. [CrossRef]

32. Eijnde, B.O.; Van Leemputte, M.; Goris, M.; Labarque, V.; Taes, Y.; Verbessem, P.; Vanhees, L.; Ramaekers, M.; Vanden Eynde, B.; Van Schuylenbergh, R.; et al. Effects of creatine supplementation and exercise training on fitness in men 55-75 yr old. J. Appl. Physiol. (1985) 2003, 95, 818-828. [CrossRef]

33. Gualano, B.; de Salles Painelli, V.; Roschel, H.; Lugaresi, R.; Dorea, E.; Artioli, G.G.; Lima, F.R.; da Silva, M.E.; Cunha, M.R.; Seguro, A.C.; et al. Creatine supplementation does not impair kidney function in type 2 diabetic patients: A randomized, double-blind, placebo-controlled, clinical trial. Eur. J. Appl. Physiol. 2011, 111, 749-756. [CrossRef]

34. Gualano, B.; Macedo, A.R.; Alves, C.R.; Roschel, H.; Benatti, F.B.; Takayama, L.; de Sa Pinto, A.L.; Lima, F.R.; Pereira, R.M. Creatine supplementation and resistance training in vulnerable older women: A randomized double- blind placebo-controlled clinical trial. Exp. Gerontol. 2014, 53, 7-15. [CrossRef] [PubMed]

35. Johannsmeyer, S.; Candow, D.G.; Brahms, C.M.; Michel, D.; Zello, G.A. Effect of creatine supplementation and drop-set resistance training in untrained aging adults. Exp. Gerontol. 2016, 83, 112-119. [CrossRef]

36. Neves, M.; Gualano, B.; Roschel, H.; Fuller, R.; Benatti, F.B.; Pinto, A.L.; Lima, F.R.; Pereira, R.M.; Lancha, A.H.; Bonfa, E. Beneficial effect of creatine supplementation in knee osteoarthritis. Med. Sci. Sports Exerc. 2011, 43, 1538-1543. [CrossRef] [PubMed]

37. Pinto, C.L.; Botelho, P.B.; Carneiro, J.A.; Mota, J.F. Impact of creatine supplementation in combination with resistance training on lean mass in the elderly. J. Cachexia Sarcopenia Muscle 2016, 7, 413-421. [CrossRef]

38. Smolarek, A.C.; McAnulty, S.R.; Ferreira, L.H.; Cordeiro, G.R.; Alessi, A.; Rebesco, D.B.; Honorato, I.C.; Laat, E.F.; Mascarenhas, L.P.; Souza-Junior, T.P. Effect of 16 weeks of strength training and creatine supplementation on strength and cognition in older adults: A pilot study. J. Exerc. Physiol. Online 2020, 23, 88-94.

39. Baumgartner, R.N.; Koehler, K.M.; Gallagher, D.; Romero, L.; Heymsfield, S.B.; Ross, R.R.; Garry, P.J.; Lindeman, R.D. Epidemiology of sarcopenia among the elderly in New Mexico. Am. J. Epidemiol. 1998, 147, 755-763. [CrossRef] [PubMed]

40. Newman, A.B.; Kupelian, V.; Visser, M.; Simonsick, E.; Goodpaster, B.; Nevitt, M.; Kritchevsky, S.B.; Tylavsky, F.A.; Rubin, S.M.; Harris, T.B. Health ABC Study Investigators Sarcopenia: Alternative definitions and associations with lower extremity function. J. Am. Geriatr. Soc. 2003, 51, 1602-1609. [CrossRef] [PubMed]

41. Macrae, P.G.; Lacourse, M.; Moldavon, R. Physical performance measures that predict faller status in community- dwelling older adults. J. Orthop. Sports Phys. Ther. 1992, 16, 123-128. [CrossRef] [PubMed]

42. Forbes, S.C.; Candow, D.G.; Ferreira, L.H.B.; Souza-Junior, T.P. Effects of Creatine Supplementation on Properties of Muscle, Bone, and Brain Function in Older Adults: A Narrative Review. J. Diet. Suppl. 2021, 1-18. [CrossRef]

43. Clynes, M.A.; Harvey, N.C.; Curtis, E.M.; Fuggle, N.R.; Dennison, E.M.; Cooper, C. The epidemiology of osteoporosis. Br. Med. Bull. 2020, 133, 105-117. [CrossRef]

44. Reginster, J.Y.; Beaudart, C.; Buckinx, F.; Bruyere, O. Osteoporosis and sarcopenia: Two diseases or one? Curr. Opin. Clin. Nutr. Metab. Care 2016, 19, 31-36. [CrossRef] [PubMed]

45. Chilibeck, P.D.; Chrusch, M.J.; Chad, K.E.; Shawn Davison, K.; Burke, D.G. Creatine monohydrate and resistance training increase bone mineral content and density in older men. J. Nutr. Health Aging 2005, 9, 352-353.

46. Candow, D.G.; Forbes, S.C.; Vogt, E. Effect of pre-exercise and post-exercise creatine supplementation on bone mineral content and density in healthy aging adults. Exp. Gerontol. 2019, 119, 89-92. [CrossRef]

47. Lobo, D.M.; Tritto, A.C.; da Silva, L.R.; de Oliveira, P.B.; Benatti, F.B.; Roschel, H.; Niess, B.; Gualano, B.; Pereira, M. Effects of long-term low-dose dietary creatine supplementation in older women. Exp. Gerontol. 2015, 70, 97-104. [CrossRef]

48. Sales, L.P.; Pinto, A.J.; Rodrigues, S.F.; Alvarenga, J.C.; Goncalves, N.; Sampaio-Barros, M.M.; Benatti, F.B.; Gualano, B.; Rodrigues Pereira, R.M. Creatine Supplementation $(3 \mathrm{~g} / \mathrm{d})$ and Bone Health in Older Women: A 2- Year, Randomized, Placebo-Controlled Trial. J. Gerontol. A Biol. Sci. Med. Sci. 2020, 75, 931-938. [CrossRef] [PubMed]

49. Eriksen, E.F. Cellular mechanisms of bone remodeling. Rev. Endocr. Metab. Disord. 2010, 11, 219-227. [CrossRef] [PubMed]

50. Boskey, A.L.; Coleman, R. Aging and bone. J. Dent. Res. 2010, 89, 1333-1348. [CrossRef]

51. Salech, F.; Marquez, C.; Lera, L.; Angel, B.; Saguez, R.; Albala, C. Osteosarcopenia Predicts Falls, Fractures, and Mortality in Chilean Community-Dwelling Older Adults. J. Am. Med. Dir. Assoc. 2020. [CrossRef] [PubMed]

52. Kirk, B.; Miller, S.; Zanker, J.; Duque, G. A clinical guide to the pathophysiology, diagnosis and treatment of osteosarcopenia. Maturitas 2020, 140, 27-33. [CrossRef] [PubMed]

53. Kirk, B.; Zanker, J.; Duque, G. Osteosarcopenia: Epidemiology, diagnosis, and treatment-facts and numbers. J. Cachexia Sarcopenia Muscle 2020, 11, 609-618. [CrossRef]

54. Atlihan, R.; Kirk, B.; Duque, G. Non-Pharmacological Interventions in Osteosarcopenia: A Systematic Review. J. Nutr. Health Aging 2021, 25, 25-32. [CrossRef]

55. Antolic, A.; Roy, B.D.; Tarnopolsky, M.A.; Zernicke, R.F.; Wohl, G.R.; Shaughnessy, S.G.; Bourgeois, J.M. Creatine monohydrate increases bone mineral density in young Sprague-Dawley rats. Med. Sci. Sports Exerc. 2007, 39, 816-820. [CrossRef] [PubMed] 
56. Gerber, I.; ap Gwynn, I.; Alini, M.; Wallimann, T. Stimulatory effects of creatine on metabolic activity, differentiation and mineralization of primary osteoblast-like cells in monolayer and micromass cell cultures. Eur. Cell. Mater. 2005, 10, 8-22. [CrossRef] [PubMed]

57. Kirk, B.; Feehan, J.; Lombardi, G.; Duque, G. Muscle, Bone, and Fat Crosstalk: The Biological Role of Myokines, Osteokines, and Adipokines. Curr. Osteoporos Rep. 2020, 18, 388-400. [CrossRef]

58. Ho-Pham, L.T.; Nguyen, U.D.; Nguyen, T.V. Association between lean mass, fat mass, and bone mineral density: A meta-analysis. J. Clin. Endocrinol. Metab. 2014, 99, 30-38. [CrossRef]

59. Kirk, B.; Phu, S.; Brennan-Olsen, S.L.; Bani Hassan, E.; Duque, G. Associations between osteoporosis, the severity of sarcopenia and fragility fractures in community-dwelling older adults. Eur. Geriatr. Med. 2020, 11, 443-450. [CrossRef]

60. Burke, D.G.; Candow, D.G.; Chilibeck, P.D.; MacNeil, L.G.; Roy, B.D.; Tarnopolsky, M.A.; Ziegenfuss, T. Effect of creatine supplementation and resistance-exercise training on muscle insulin-like growth factor in young adults. Int. J. Sport Nutr. Exerc. Metab. 2008, 18, 389-398. [CrossRef]

61. Farshidfar, F.; Pinder, M.A.; Myrie, S.B. Creatine Supplementation and Skeletal Muscle Metabolism for Building Muscle MassReview of the Potential Mechanisms of Action. Curr. Protein Pept. Sci. 2017, 18, 1273-1287. [CrossRef]

62. Saremi, A.; Gharakhanloo, R.; Sharghi, S.; Gharaati, M.R.; Larijani, B.; Omidfar, K. Effects of oral creatine and resistance training on serum myostatin and GASP-1. Mol. Cell. Endocrinol. 2010, 317, 25-30. [CrossRef]

63. El-Kotob, R.; Ponzano, M.; Chaput, J.P.; Janssen, I.; Kho, M.E.; Poitras, V.J.; Ross, R.; Ross-White, A.; Saunders, T.J.; Giangregorio, L.M. Resistance training and health in adults: An overview of systematic reviews. Appl. Physiol. Nutr. Metab. 2020, 45, S165-S179. [CrossRef]

64. Kirk, B.; Prokopidis, K.; Duque, G. Nutrients to mitigate osteosarcopenia: The role of protein, vitamin D and calcium. Curr. Opin. Clin. Nutr. Metab. Care 2021, 24, 25-32. [CrossRef]

65. Jakicic, J.M.; Powell, K.E.; Campbell, W.W.; Dipietro, L.; Pate, R.R.; Pescatello, L.S.; Collins, K.A.; Bloodgood, B.; Piercy, K.L. 2018 physical activity guidelines advisory committee* Physical Activity and the Prevention of Weight Gain in Adults: A Systematic Review. Med. Sci. Sports Exerc. 2019, 51, 1262-1269. [CrossRef] [PubMed]

66. Goodpaster, B.H.; Carlson, C.L.; Visser, M.; Kelley, D.E.; Scherzinger, A.; Harris, T.B.; Stamm, E.; Newman, A.B. Attenuation of skeletal muscle and strength in the elderly: The Health ABC Study. J. Appl. Physiol. 2001, 90, 2157-2165. [CrossRef] [PubMed]

67. Kim, Y.S.; Lee, Y.; Chung, Y.S.; Lee, D.J.; Joo, N.S.; Hong, D.; Song, G.; Kim, H.J.; Choi, Y.J.; Kim, K.M. Prevalence of sarcopenia and sarcopenic obesity in the Korean population based on the Fourth Korean National Health and Nutritional Examination Surveys. J. Gerontol. A Biol. Sci. Med. Sci. 2012, 67, 1107-1113. [CrossRef]

68. Roh, E.; Choi, K.M. Health Consequences of Sarcopenic Obesity: A Narrative Review. Front. Endocrinol. (Lausanne) 2020, 11, 332. [CrossRef] [PubMed]

69. Jee, S.H.; Sull, J.W.; Park, J.; Lee, S.Y.; Ohrr, H.; Guallar, E.; Samet, J.M. Body-mass index and mortality in Korean men and women. N. Engl. J. Med. 2006, 355, 779-787. [CrossRef]

70. Despres, J.P. Abdominal obesity and cardiovascular disease: Is inflammation the missing link? Can. J. Cardiol. 2012, 28, 642-652. [CrossRef] [PubMed]

71. Alberti, K.G.; Zimmet, P.; Shaw, J.; IDF Epidemiology Task Forcesensus Group. The metabolic syndrome-A new worldwide definition. Lancet 2005, 366, 1059-1062. [CrossRef]

72. Lee, S.Y.; Park, H.S.; Kim, D.J.; Han, J.H.; Kim, S.M.; Cho, G.J.; Kim, D.Y.; Kwon, H.S.; Kim, S.R.; Lee, C.B.; et al. Appropriate waist circumference cutoff points for central obesity in Korean adults. Diabetes Res. Clin. Pract. 2007, 75, 72-80. [CrossRef] [PubMed]

73. Garvey, W.T.; Mechanick, J.I.; Brett, E.M.; Garber, A.J.; Hurley, D.L.; Jastreboff, A.M.; Nadolsky, K.; Pessah- Pollack, R.; Plodkowski, R. Reviewers of the AACE/ACE Obesity Clinical Practice Guidelines American Association of Clinical Endocrinologists and American College of Endocrinology Comprehensive Clinical Practice Guidelines for Medical Care of Patients with Obesity. Endocr. Pract. 2016, 22, 1-203. [CrossRef]

74. Batsis, J.A.; Mackenzie, T.A.; Lopez-Jimenez, F.; Bartels, S.J. Sarcopenia, sarcopenic obesity, and functional impairments in older adults: National Health and Nutrition Examination Surveys 1999-2004. Nutr. Res. 2015, 35, 1031-1039. [CrossRef] [PubMed]

75. Forbes, S.; Candow, D.; Krentz, J.; Roberts, M.; Young, K. Body fat changes following creatine supplementation and resistance training in adults $>50$ years of age: A meta-analysis. J. Funct. Morphol. Kinesiol. 2019, 4, 62. [CrossRef]

76. Lee, N.; Kim, I.; Park, S.; Han, D.; Ha, S.; Kwon, M.; Kim, J.; Byun, S.H.; Oh, W.; Jeon, H.B.; et al. Creatine inhibits adipogenesis by downregulating insulin-induced activation of the phosphatidylinositol 3-kinase signaling pathway. Stem Cells Dev. 2015, 24, 983-994. [CrossRef]

77. Chouchani, E.T.; Kazak, L.; Spiegelman, B.M. New Advances in Adaptive Thermogenesis: UCP1 and Beyond. Cell. Metab. 2019, 29, 27-37. [CrossRef] [PubMed]

78. Wakatsuki, T.; Hirata, F.; Ohno, H.; Yamamoto, M.; Sato, Y.; Ohira, Y. Thermogenic responses to high-energy phosphate contents and/or hindlimb suspension in rats. Jpn. J. Physiol. 1996, 46, 171-175. [CrossRef]

79. Kazak, L.; Chouchani, E.T.; Lu, G.Z.; Jedrychows, P.; Bare, C.J.; Mina, A.I.; Kumari, M.; Zhang, S.; Vuckovic, I.; Laznik-Bogoslavski, D.; et al. Genetic Depletion of Adipocyte Creatine Metabolism Inhibits Diet-Induced Thermogenesis and Drives Obesity. Cell. Metab. 2017, 26, 693. [CrossRef]

80. Perna, M.K.; Kokenge, A.N.; Miles, K.N.; Udobi, K.C.; Clark, J.F.; Pyne-Geithman, G.J.; Khuchua, Z.; Skelton, M.R. Creatine transporter deficiency leads to increased whole body and cellular metabolism. Amino Acids 2016, 48, 2057-2065. [CrossRef] 
81. Kazak, L.; Rahbani, J.F.; Samborska, B.; Lu, G.Z.; Jedrychowski, M.P.; Lajoie, M.; Zhang, S.; Ramsay, L.C.; Dou, F.Y.; Tenen, D.; et al. Ablation of adipocyte creatine transport impairs thermogenesis and causes diet-induced obesity. Nat. Metab. 2019, 1, 360-370. [CrossRef]

82. Fried, L.P.; Tangen, C.M.; Walston, J.; Newman, A.B.; Hirsch, C.; Gottdiener, J.; Seeman, T.; Tracy, R.; Kop, W.J.; Burke, G.; et al. Cardiovascular Health Study Collaborative Research Group Frailty in older adults: Evidence for a phenotype. J. Gerontol. A Biol. Sci. Med. Sci. 2001, 56, 146. [CrossRef]

83. Song, X.; Mitnitski, A.; Rockwood, K. Prevalence and 10-year outcomes of frailty in older adults in relation to deficit accumulation. J. Am. Geriatr. Soc. 2010, 58, 681-687. [CrossRef] [PubMed]

84. Rochat, S.; Cumming, R.G.; Blyth, F.; Creasey, H.; Handelsman, D.; Le Couteur, D.G.; Naganathan, V.; Sambrook, P.N.; Seibel, M.J.; Waite, L. Frailty and use of health and community services by community-dwelling older men: The Concord Health and Ageing in Men Project. Age Ageing 2010, 39, 228-233. [CrossRef] [PubMed]

85. Thompson, M.Q.; Theou, O.; Karnon, J.; Adams, R.J.; Visvanathan, R. Frailty prevalence in Australia: Findings from four pooled Australian cohort studies. Australas. J. Ageing 2018, 37, 155-158. [CrossRef] [PubMed]

86. Martin, F.C.; Ranhoff, A.H. Frailty and Sarcopenia; Falaschi, P., Marsh, D., Eds.; Orthogeriatrics: The Management of Older Patients with Fragility Fractures; Springer: Cham, Switzerland, 2021; pp. 53-65.

87. Oktaviana, J.; Zanker, J.; Vogrin, S.; Duque, G. The Effect of beta-hydroxy-beta-methylbutyrate (HMB) on Sarcopenia and Functional Frailty in Older Persons: A Systematic Review. J. Nutr. Health Aging 2019, 23, 145-150. [CrossRef] [PubMed]

88. Rockwood, K.; Song, X.; MacKnight, C.; Bergman, H.; Hogan, D.B.; McDowell, I.; Mitnitski, A. A global clinical measure of fitness and frailty in elderly people. CMAJ 2005, 173, 489-495. [CrossRef]

89. Collins, J.; Longhurst, G.; Roschel, H.; Gualano, B. Resistance Training and Co-supplementation with Creatine and Protein in Older Subjects with Frailty. J. Frailty Aging 2016, 5, 126-134. [PubMed]

90. Riesberg, L.A.; Weed, S.A.; McDonald, T.L.; Eckerson, J.M.; Drescher, K.M. Beyond muscles: The untapped potential of creatine. Int. Immunopharmacol. 2016, 37, 31-42. [CrossRef]

91. Dalle, S.; Rossmeislova, L.; Koppo, K. The Role of Inflammation in Age-Related Sarcopenia. Front. Physiol. 2017, 8, 1045. [CrossRef]

92. Van Epps, P.; Oswald, D.; Higgins, P.A.; Hornick, T.R.; Aung, H.; Banks, R.E.; Wilson, B.M.; Burant, C.; Graventstein, S.; Canaday, D.H. Frailty has a stronger association with inflammation than age in older veterans. Immun. Ageing 2016, 13, 1-9. [CrossRef] [PubMed]

93. Hassan, E.B.; Imani, M.; Duque, G. Is Physical Frailty a Neuromuscular Condition? J. Am. Med. Dir. Assoc. 2019, 20 , 1556-1557. [CrossRef] [PubMed]

94. Uchmanowicz, I. Oxidative Stress, Frailty and Cardiovascular Diseases: Current Evidence. Adv. Exp. Med. Biol. 2020, 1216, 65-77. [PubMed]

95. Webster, J.M.; Kempen, L.J.A.P.; Hardy, R.S.; Langen, R.C.J. Inflammation and Skeletal Muscle Wasting During Cachexia. Front. Physiol. 2020, 11, 597675. [CrossRef] [PubMed]

96. Wyart, E.; Bindels, L.B.; Mina, E.; Menga, A.; Stanga, S.; Porporato, P.E. Cachexia, a Systemic Disease beyond Muscle Atrophy. Int. J. Mol. Sci. 2020, 21, 8592. [CrossRef]

97. Fairman, C.M.; Kendall, K.L.; Hart, N.H.; Taaffe, D.R.; Galvao, D.A.; Newton, R.U. The potential therapeutic effects of creatine supplementation on body composition and muscle function in cancer. Crit. Rev. Oncol. Hematol. 2019, 133, 46-57. [CrossRef]

98. Jatoi, A.; Steen, P.D.; Atherton, P.J.; Moore, D.F.; Rowland, K.M.; Le-Lindqwister, N.A.; Adonizio, C.S.; Jaslowski, A.J.; Sloan, J.; Loprinzi, C. A double-blind, placebo-controlled randomized trial of creatine for the cancer anorexia/weight loss syndrome (N02C4): An Alliance trial. Ann. Oncol. 2017, 28, 1957-1963. [CrossRef]

99. Bourgeois, J.M.; Nagel, K.; Pearce, E.; Wright, M.; Barr, R.D.; Tarnopolsky, M.A. Creatine monohydrate attenuates body fat accumulation in children with acute lymphoblastic leukemia during maintenance chemotherapy. Pediatr. Blood Cancer. 2008, 51, 183-187. [CrossRef]

100. Norman, K.; Stubler, D.; Baier, P.; Schutz, T.; Ocran, K.; Holm, E.; Lochs, H.; Pirlich, M. Effects of creatine supplementation on nutritional status, muscle function and quality of life in patients with colorectal cancer-A double blind randomised controlled trial. Clin. Nutr. 2006, 25, 596-605. [CrossRef]

101. Lonbro, S.; Dalgas, U.; Primdahl, H.; Overgaard, J.; Overgaard, K. Feasibility and efficacy of progressive resistance training and dietary supplements in radiotherapy treated head and neck cancer patients-The DAHANCA 25A study. Acta Oncol. 2013, 52, 310-318. [CrossRef] 